\title{
Editorial
}

\section{Reforming the Basel Accord}

In its third and most recent consultation paper, published on 29th April, 2003, the Basel Committee on Banking Supervision reaffirmed the essential elements of its proposed New Capital Accord (Basel II) with the expectation that all countries with international banks would begin implementing Basel II by the end of 2003. Basel II would significantly change the way banks and regulators calculate the amount of capital they should hold against their risk-based assets. Basel II proposes to make significant changes to the original 1988 Capital Accord, which was a landmark international agreement that committed the world's richest countries to building and maintaining capital levels in their banking sectors. Basel II consists of three pillars: minimum capital requirements; the supervisory review process; and improved disclosure to enhance market discipline. Although Basel II has attracted much positive comment for doing more to improve credit risk management, it has been criticised as being pro-cyclical, favouring big banks with sophisticated risk measurement systems and increasing financial fragility in developing countries. Indeed, the proposed Accord is premised on the beneficial effects of market discipline and supervisory discretion, but it fails to take account of market failure and regulatory capture.

The 1988 Capital Accord's original intention was to prevent a slide in international capital ratios resulting from aggressive competition for market share by the leading banks during the mid-1980s. Banks actively engaged in international transactions were required to hold capital equal to at least 8 per cent of their risk-weighted assets. This capital adequacy standard was intended to prevent banks from increasing their exposure to credit risk by imprudently incurring greater leverage. The Accord's use of a risk-based structure for calculating capital ratios, which assigns different capital weights to fewer asset classes (both on- and off-balance sheet), has been one of its greatest contributions. This method not only marked a significant improvement from the previously used gearing ratio method used by national regulators, but it also created less incentive for off-balance sheet activities. In the 1990s, periodic amendments to the Accord extended its capital adequacy requirements to market risk, as well as allowing banks to use value-at-risk (VaR) models.

A major weakness, however, of the 1988 Accord was that its rather crude risk weightings led banks to adopt cosmetic changes to their credit risk portfolios. The Basel Committee recognised this problem in 1999 in its first consultation report on Basel II. The Committee observed that the 'current risk weighting of assets results, at best, is a crude measure of economic risk, primarily because degrees of credit risk exposure are not sufficiently calibrated as to adequately differentiate between borrowers' differing default risks'. The report also noted the increasing tendency of banks to arbitrage their regulatory capital and exploit differences between true economic risk and risk measured under the Accord.

The Committee sought to address these problems by proposing three mutually reinforcing pillars that comprise the frame- 
work for assessing capital adequacy. The first pillar is the minimum regulatory capital charge that would maintain the 1988 Accord's 8 per cent capital adequacy ratio but would change how the risk weights to the capital ratio are determined. It would do so by adopting a revised standardised approach for calculating capital charges at the majority of banks, while replacing the existing system of credit risk weightings with external agencies' credit assessments to determine risk weights. In contrast, sophisticated banks could opt for an internal ratings based (IRB) approach that would place greater emphasis on a bank's internal credit risk-rating practices. Both the revised standardised approach and the IRB approach represent a fundamental shift in the Committee's view that the Capital Accord should be more risk-sensitive. The use of more sophisticated risk measures will effectively deregulate, or contract out, the determination of capital requirements to banks.

The second pillar is supervisory review, which intends 'to ensure not only that banks have adequate capital to support all the risks in their business, but also to encourage banks to develop and use better risk management techniques in monitoring and managing these risks'. This pillar encourages supervisors to assess banks' internal approaches to capital allocation and internal assessments of capital adequacy. Subject to the discretion of national regulators, it provides an opportunity for the supervisor to indicate where such approaches do not appear to be sufficient. The third pillar recognises that market discipline has the potential to reinforce capital regulation and other supervisory efforts to ensure the safety and soundness of the banking system. To this end, the Committee has proposed a wide range of disclosure initiatives designed to add more transparency to the risk and capital positions of a bank.
The Basel II proposal suffers from a number of serious weaknesses and should not be implemented into national regulatory systems. First, the use of external credit assessment agencies creates problems concerning how to ensure that these agencies have the appropriate incentives to consider the full implications of their ratings on overall systemic risk. One risk in using these external agents to set prudential standards is the creation of incentives for them to act either in their own interests or those of the borrower in the hope of maximising their own gains through favourable ratings. These issues also then call into question the quality of each rating agency as well as the standards they apply. Consequently, there needs to be some mechanism to reduce such perverse incentive effects for both private credit agencies and their client banks so that they are unable to ignore the costs of increasing systemic risk when maximising their short-run profits. In economics, this is known as the public good problem.

Secondly, pillar 2 substantially increases the degree to which supervisors can exercise discretion, and hence is vulnerable to government failure. If this discretion is not used for the public good, then regulation will be ineffective. In many countries, banks and regulators have more opportunity and incentive to extract benefits at public cost because institutions that limit rent-seeking are weak. This is of particular concern in developing countries where regulatory independence and accountability have little institutional or legal support. Thirdly, Basel II is pro-cyclical, especially the IRB approach. The Accord should impose counter-cyclical requirements, such as higher capital charges during boom times and lower ones during a downturn.

Fourthly, because the Basel Committee has stated that Basel II will apply to 'all countries where international banks operate', it fails to take account of the differences in economic and financial structure 
of developing countries. Developing countries experience greater macroeconomic volatility and greater volatility in financial flows, and thus are more vulnerable to external shocks. The pro-cyclical effect of Basel II would have a disproportionate impact on developing countries and thereby undermine economic development. Finally, the increased risk sensitivity of Basel II does not provide an incentivecompatible framework in which bankers are incentivised to assume more of the costs of the risk they create. For example, personal liability for bank owners should be used as a disincentive to reduce the social cost of risky behaviour.

The Committee intends to finalise the new Accord by 31st December, 2003, and national governments will be encouraged to adopt the necessary legislation to implement the standards beginning in 2004 with a final deadline for the end of 2006. Given the weaknesses of Basel II, national regulators from non-G10 countries - especially developing and emerging market countries - should devise an alternative Capital Accord that would more accurately take into account the financial risks facing these countries.

\section{Kern Alexander}

Butterworths Senior Research Fellow, International Financial Regulation, and Postgraduate Tutor in Law, Institute of Advanced Legal Studies, UK 